A Szegedi Tudományegyetem Általános Orvostudományi Kar Fül-Orr-Gégészeti és Fej-Nyaksebészeti Klinika ${ }^{1}$, a Börgyógyászati és Allergológiai Klinika² és az Arc-, Állcsont- és Szájsebészeti Klinika ${ }^{3}$ közleménye

\title{
Ajtószárny lebenyek speciális felhasználási lehetőségei fej-nyaki tumoros beteganyagunkon
}

\author{
DR. VASS GÁBOR ${ }^{1}$, DR. MOHOS GÁBOR², DR. PACZONA RÓBERT ${ }^{3}$, \\ DR. VARGA JÁNOS ${ }^{2}$, DR. IVÁN LÁSZLÓ ${ }^{1}$, DR. ROVÓ LÁSZLÓ ${ }^{1}$ \\ DOI: $10.21755 /$ MTO.2015.058.0004.006
}

Érkezett: 2015. november 9.

\section{ÖSSZEFOGLALÁS}

A rosszindulatú fej-nyaki daganatok radikális eltávolítása után visszamaradt, speciális anatómiai lokalizációjú defektusok pótlása (részleges vagy teljes orrhiány) vagy a szövődmények (oro- és pharyngocutan fisztula) sebészi megoldása bonyolult, kihívást jelentő feladat. Jelen közleményünkben az ajtószárny lebenyekkel végzett rekonstrukciós mútétek kedvező tapasztalatát szeretnénk ismertetni, amelyek az anatómiai és élettani funkció helyreállítását szolgálják fej-nyaki tumorok radikális eltávolítása után visszamaradt, illetve szövődményként kialakult defektusok pótlására nagy mútéti megterhelés nélkül olyan speciális helyzetekben, amikor a környezet egy része heges, sugárkárosodott vagy az anatómiai viszonyok miatt korlátozottak a szövetvételi lehetőségek.

\section{Kulcsszavak: $\quad$ Fej-nyaki daganatok; Lebenyplasztika; Rekonstruktiv sebészet;}

G. Vass, G. Mohos, R. Paczona, J. Varga, L. Iván, L. Rovó: Application alternatives of turnover flaps in special cases of head and neck cancer

The reconstruction of tissue defects in special anatomic localization (e.g. partial or total resection of the nose) or the surgical treatment of certain complications (e.g. orocutaneous or pharyngocutaneous fistula) occurring after the radical resection of malignant head and neck tumors is a complicated, challenging problem for the surgeon. In the present article we discuss our favorable experience with turnover flaps in reconstructive surgery, which were used to restore the anatomical and physiological function without significant operative burden for the patient in some cases. These defects were created either by the radical resection of head and neck tumors, or have developed as a postoperative complication. Turnover flaps were used in such special cases, when the surgical field was surrounded by partially scarred, irradiated skin or tissue harvesting was limited due to the anatomical localization.

Keywords: $\quad$ Head and neck neoplasms - Surgery;

Reconstructive surgical procedures - Methods; Surgical flaps; 


\section{BEVEZETÉS}

Az ajtószárny lebenyek (turnover flaps) olyan lebenyek, amelyek a vérellátást biztosító forgáspontjuk mentén 180 fokkal átfordítva kerülnek a befogadó területükre. A bőrből és subcutan zsírszövetből álló bőrlebenyek random vérellátásúnak, míg a fasciából és izomból képzett ajtószárny izomlebenynek akár érnyelesek is lehetnek. Széles körü alkalmazhatóságukról számos közlemény jelent meg a nemzetközi szakirodalomban (1, 4, 11, 12). A reverz átfordított bőr, fascia, illetve izomlebenyek leggyakoribb felhasználási területei a következők: alsó végtagi szövethiányok és a kéz ujjainak defektusai, sacralis decubitus, myelomeningocele, mellkasi defektus, tracheostoma, pharyngocutan és orocutan fisztula valamint az orr porcos vázának defektusai $(5,6,9,10)$.

Jelen közleményünkben az ajtószárny lebenyek speciális felhasználási lehetőségeit szeretnénk bemutatni, az irodalomban részben már leírt mútéti technikák adaptálását illetve módosítását saját betegeinkre vonatkozóan.

\section{ANYAG ÉS MÓDSZER}

\section{1. eset}

51 éves nőbetegnél előzetes definitív sugárkezelést követően, reziduális hypopharynx tumor miatt végeztünk teljes gége eltávolítást és nyaki blokkdisszekciót. A sugárkezelés miatti rossz gyógyhajlam, illetve a posztoperatív parenterális antibiotikum kezelés ellenére fellépő szuperinfekció következtében pharyngocutan fisztula alakult ki, amely hoszszan tartó konzervatív kezelésre (triklór-ecetsavas edzés, bórsavpor, hámosító kenőcsök) sem gyógyult meg. Napjainkban a nyálsipoly kialakulásának megelőzésére vagy gyógyulásának elősegítésére javasolt parenterális protonpupa-gátló terápia jótékony hatása akkoriban még nem volt ismert. Az ugyancsak korszerű sebkezelési módszernek számító VAC (Vacuum Assisted Closure) pedig sajnos nem elérhető Klinikánkon. Több alkalommal kíséreltük meg a nyaki, garati defektus zárását lokálisan bőr-platysma, valamint pectoralis major (PM), majd latissimus dorsi (LD) myocutan lebenyekkel, de a sipoly méretének csökkenését leszámítva tartós eredményt nem értünk el (1. a ábra). Klinikánkon ezeket a jó vérellátású, stabil szövetpótlást biztosító érnyeles izom-bőr lebenyeket már évtizedek óta rutinszerűen és nagy számban alkalmazzuk a fej-nyaki kiterjedt defektusok pótlására. Véleményünk szerint ennél a betegünknél az előzetes sugárkezelés okozta szövetkárosodás és a társuló multirezisztens baktériumtörzsek okozta krónikus sebfertőzés miatt nem tudtunk tartós eredményt elérni a fentebb felsorolt lebenyekkel. Utolsó lehetőségként alkalmaztuk a betegnél a sipoly széle mentén kialakított ajtószárny lebenyt a garat folytonosságának helyreállítására, melyet a korábbi myocutan lebeny megmaradt, környezetéhez képest relativ jobb vérellátású részéből alakítottunk ki (1. b ábra). A fennmaradó defektust a környező bőr mobilizációjával és félvastag bőr átültetésével fedtük. A gyógyulás ez esetben maradéktalan volt, a beteg jelenleg is tumormentes, per os étkezése teljes (1. c ábra).

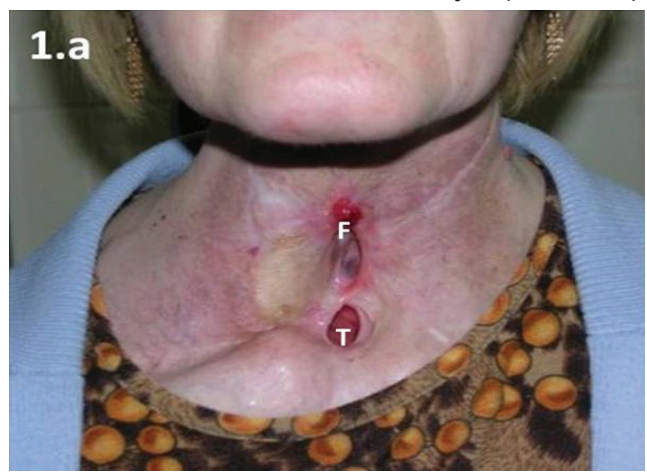

1. a ábra Preoperativ felvétel (F: fisztula, T: tracheostoma) 


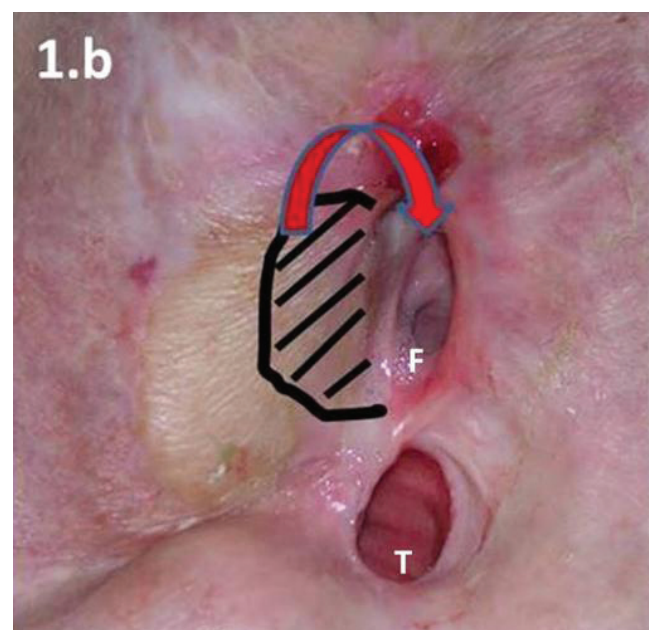

1. b ábra Mútéti terv az ajtószárny lebeny kialakítására

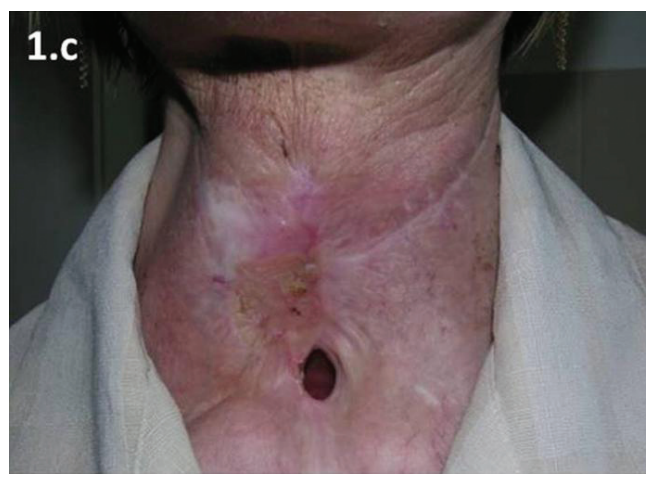

1. c ábra Gyógyult állapot a mütét után két hónappal

\section{2. eset}

83 éves férfibetegnél a bal submandibularis nyálmirigyből kiinduló, nyaki áttétet adó rosszindulatú daganat (adenoid cysticus carcinoma) miatt történt nyálmirigy eltávolítás a környező infiltrált lágyrészekre kiterjesztve, radikális nyaki blokkdisszekcióval egybekötve. A posztoperatív szakban a carotis artériából észlelt masszív vérzés miatt akut exploráció történt. A széles spektrumú parenterális antibiotikumkezelés ellenére fellépő sebfertőzés következményeként sebszétválás, orocutan fisztula alakult ki, sőt rövid szakaszon a mandibula is szabaddá vált (2. a ábra). A sipoly mérete miatt konzervatív kezelés nem jött szóba, és a beteg életkora, valamint kísérő betegségei (idült ischaemiás szívbetegség, cukorbetegség) miatt a legkisebb mútéti megterhelést jelentő szövetpótlási lehetőséget választottuk, miután a többszöri direkt sebzárás, re-sutura sikertelen volt. A nyak bőréből kialakított háromszög alakú ajtószárny lebenynyel zártuk a defektust, a mandibula szabadon lévő szakaszáról a corticalis csontot reszekáltuk (2. $b$ ábra). A nyak bőrét mobilizálva és ezt a tarkó felől nyelezett rotációs lebennyel kombinálva fedtük be teljesen a defektust (2. c ábra). A sebgyógyulás zavartalan volt (2. $d$ ábra). A sipoly megszűnt, a garat anatómiai és élettani funkciója helyreállt. 


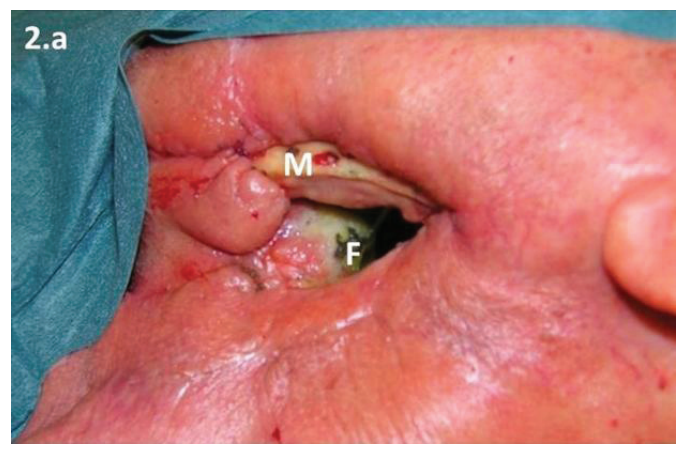

2. a ábra Preoperativ felétel (M: mandibula, F: fisztula)

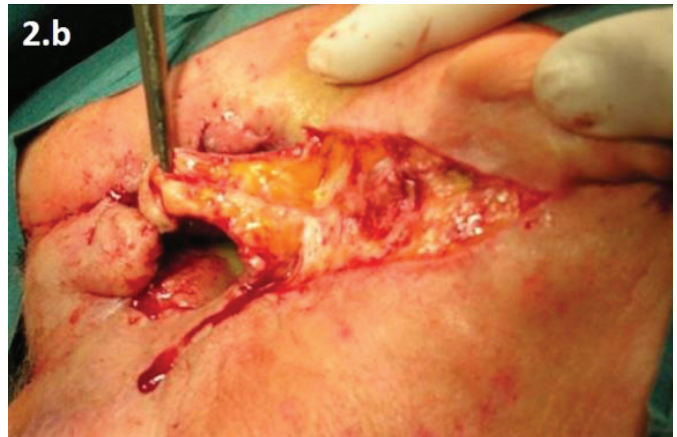

2. b ábra Az ajtószárny lebeny kialakitása és átfordítása a defektusba

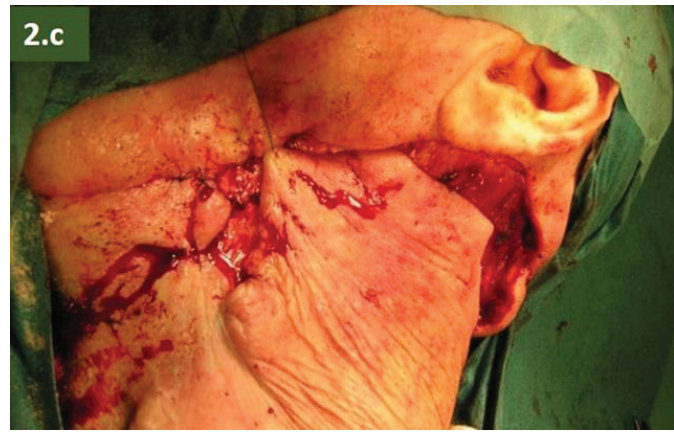

2. c ábra A sebfelszín teljes fedése lebenyforgatással

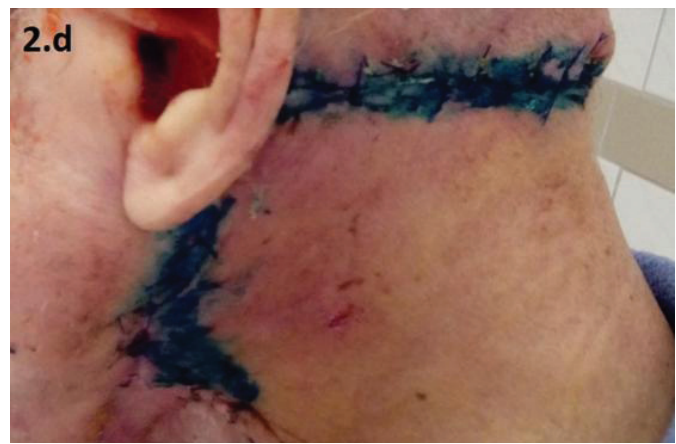

2. d ábra Gyógyult állapot mütét után 10 nappal 


\section{3. eset}

63 éves férfibetegnél az orr bal felét teljes vastagságában destruáló carcinoma spinocellulare miatt történt radikális reszekció, a szövettani vizsgálat alapján komplett eltávolítás. Fél év tumormentességet követően végeztük a három lépcsős rekonstrukciós mútétsorozatot: első lépésben kialakítottuk az orr belső bélését ajtószárny lebenyekkel, felépítettük a porcos orrváz hiányzó részét és jobb oldali homloklebennyel fedtük a defektust. Második lépésként három hét múlva a homloklebeny felemelése, elvékonyítása, kontúrkorrekciók elvégzése, majd újabb 3 hét elteltével a lebeny nyelének átvágása következett.

$A z$ orrnyálkahártya pótlására alkalmazott ajtószárny bőrlebeny előnye a stabil, elégséges vérellátású, mégsem voluminózus szövetpótlás, amelyre késleltetés nélkül felépíthetjük az orr porcos vázának hiányzó részeit.
$\mathrm{Az}$ orrüregbe fordított bőr pedig megfelelő pótlását adja a hiányzó nyálkahártyának, megelőzve a pörkösödést és biztosítva az orrlégzési funkciót. Az orr porcos vázának rekonstrukciójához septum porcot és concha porcot használtunk fel: az előbbiből orrháti és columella graftot, utóbbiból orrszárnyi graftot képeztünk; egy esetben pedig a porcos septum defektusát bordaporccal pótoltuk. Az orr külső borítását a supratrochlearis artériára nyelezett homloklebeny biztosította.

Hat betegünknél alkalmaztuk az arc bőréből kialakított ajtószárny lebenyeket az orr belső bélésének kialakítására, rosszindulatú, kiterjedt bőrdaganat miatt végzett teljes vagy részleges orr amputációt követően (I. táblázat); egy esetünk kapcsán fentebb mutattuk be mútéti technikánkat és az elért eredményt (3. $a-c a ́ b r a)$.

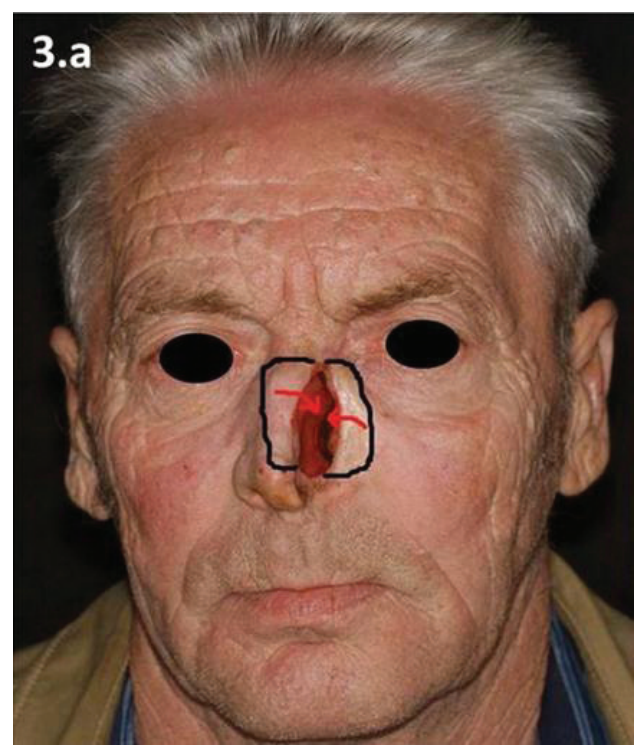

3. a ábra Mütéti terv az orrüreg belső bélésének kialakitására ajtószárny lebenyekkel 


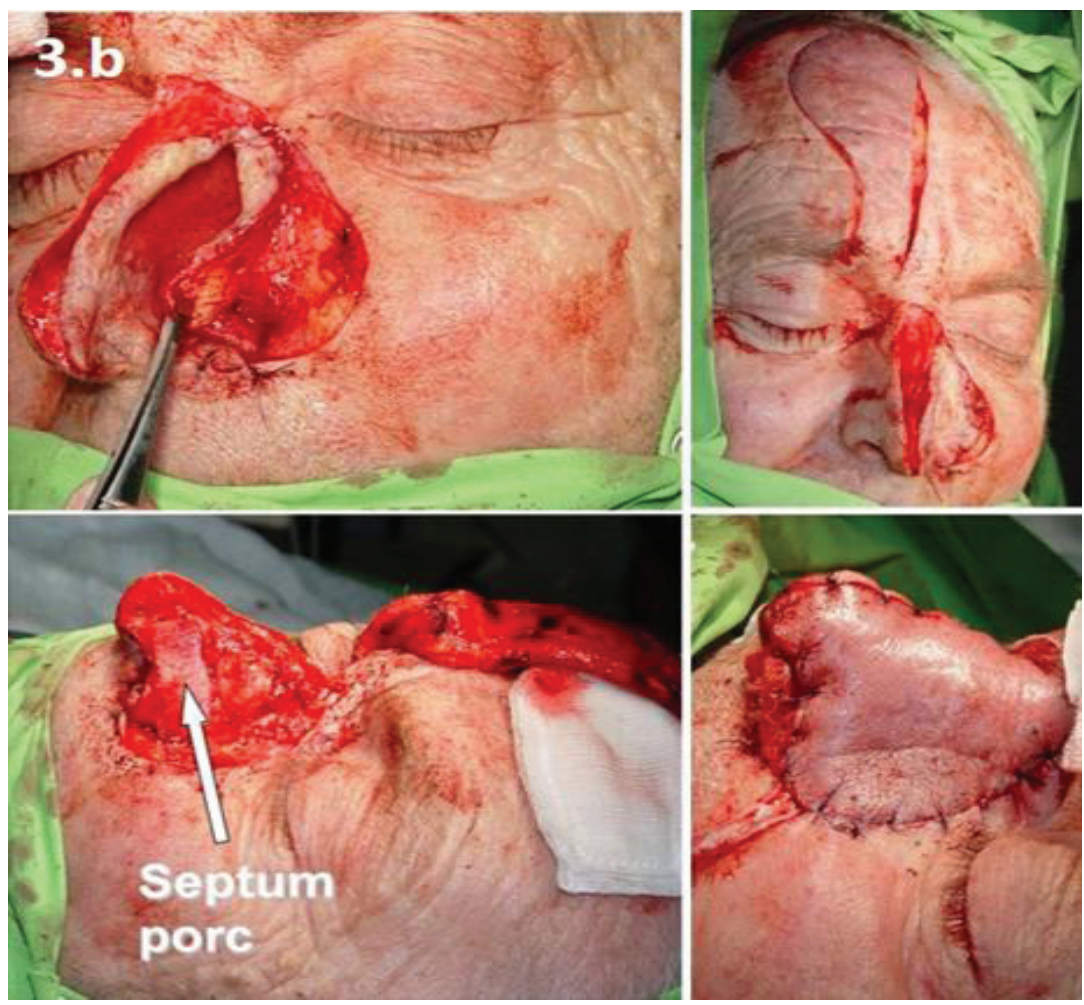

3. b ábra A mútét lépései (orrnyálkahártya pótlás, porcos váz felépítés és fedés homloklebennyel)

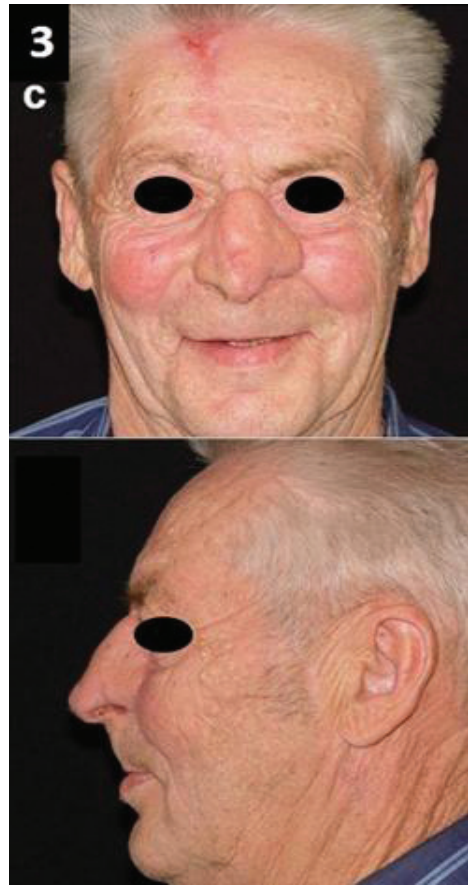

3. c ábra Gyógyult állapot 


\section{I. táblázat Összefoglaló táblázat az ajtószárny lebennyel operált orrtumoros betegeink adatairól (2005-2015)}

\begin{tabular}{|c|c|c|c|}
\hline \multicolumn{4}{|c|}{ Kiterjedt orrdefektusok } \\
\hline Nem & Kor (év) & $\begin{array}{l}\text { Defektus lokalizációja } \\
\text { és kiterjedése }\end{array}$ & Szövettani típus \\
\hline nő & 85 & $\begin{array}{c}\text { jobb oldali teljes por- } \\
\text { cos orrfél }\end{array}$ & cc. basocellulare \\
\hline nő & 72 & $\begin{array}{l}\text { bal oldali teljes orr- } \\
\text { szárny és orrcsúcs }\end{array}$ & cc. basocellulare \\
\hline nő & 57 & $\begin{array}{l}\text { orrcsúcs, columella és } \\
\text { septum elülső része }\end{array}$ & cc. planocellulare \\
\hline nő & 79 & $\begin{array}{c}\text { jobb oldali teljes por- } \\
\text { cos orrfél }\end{array}$ & cc. planocellulare \\
\hline férfi & 63 & $\begin{array}{l}\text { bal oldali teljes por- } \\
\text { cos orrfél }\end{array}$ & cc. planocellulare \\
\hline férfi & 58 & $\begin{array}{c}\text { kétoldali teljes por- } \\
\text { cos orr és részleges } \\
\text { septum }\end{array}$ & cc. basocellulare \\
\hline
\end{tabular}

\section{MEGBESZÉLÉS}

$\mathrm{Az}$ orocutan és pharyngocutan fisztula kialakulásának incidenciája előzetes sugárkezelést követően vagy anélkül 2-66\% közé tehető (7). Bár a sipolyok egy része hosszadalmas konzervatív kezelésre, sebészi beavatkozás nélkül is bezáródhat, ez minden esetben a gyógyulási idő jelentős megnyúlását eredményezi és a beteg számára is hatalmas pszichés és szociális terhet jelent ( $p l$. tartós tápszonda vagy gastrostoma viselés). A preoperatív sugárkezelés és a fisztula kialakulása közötti egyértelmű összefüggést számos közlemény igazolta (5); kóroki szerepe továbbá a beteg életkorának, tápláltságának, a sebfertőzésnek és a daganat stádiumának van (7). A sipoly gyakori előfordulása ellenére sebészi ellátása az esetek nagy részében kihívást jelentő, nehéz feladat.

A fej-nyaki daganatos betegek esetén, akiknél sebgyógyulási zavar (oro-, vagy pharyngocutan fisztula, sebszétválás, defektusképződés) alakult ki, jellemzően a sipoly körüli bőr sugárkárosodott, heges, rossz vérellátású. $\mathrm{Az}$ irodalomban számos rekonstrukciós lehetőséget írtak már le a fisztulák sebészi megoldására, kezdve a fasciocutan szigetlebenyektől, a lokális és távoli bőr- és izomlebenyeken át a szabadlebenyekig $(1,5,7,11)$. Mindezen módszerek ellenére a sipoly kiújulási gyakorisága meglehetősen magas - ami magában rejtheti a lokális tumor recidívát is - PM myocutan lebenyek esetében ez az érték közel 35\%-ra tehető (7).

Az elmúlt 10 évben (2005-2015) Klinikánkon T3-T4 stádiumú, rosszindulatú algarat és gége daganat miatt 106 betegnél végeztünk parciális pharynx reszekcióval egybekötött teljes gégeeltávolítást. Pharyngocutan fisztula 23 esetben alakult ki (21,7\%). Közülük 12 betegünknél $(52,2 \%)$ a sipoly konzervatív kezelésre záródott; 11 betegnél $(47,8 \%)$ mútéti megoldás vált szükségessé a konzervatív kezelés tartós sikertelensége miatt. A revíziós operáción átesett 11 betegünk közül 7 esetben (63,6\%) a sipoly több rétegben történő zárása, vagy nagyobb defektus esetén PM lebenyes rekonstrukció végleges megoldást eredményezett. Négy esetben $(36,4 \%)$ azonban a fenti mútétek sikertelenségét követően döntöttünk utolsó alternativaként az ajtószárny lebeny alkalmazása mellett a fisztula zárására. Ezen négy betegünk közül háromnál primeren onkológiai kezelés, kemo-radioterápia történt. Orocutan sipoly mindössze egy betegünknél alakult ki (2. a-d ábra).

Fenti tapasztalatainknak megfelelően az ismételt nagy mútéti megterhelést kerülendően igyekeztünk a lehető legbiztosabb és legegyszerűbb mütéti megoldást megtalálni ezen öt 
betegünknél, amelyet a random vérellátású ajtószárny lebenyek jelentették.

$\mathrm{Az}$ orrszárny pótlására alkalmazott, a nasolabialis régióból forgatott ajtószárny bőrlebenyt először Spear és munkatársai írták le 1987-ben. Azóta a mútéti technika számos módosítása került közlésre a defektus lokalizációja és kiterjedése alapján $(2,3,8)$.

$A z$ orr porcos vázát és a perialaris régiót érintő, a tumorok kiterjedt reszekcióját követően visszamaradt orrdefektusok rekonstrukciója komoly sebészi kihívást jelentő feladat. Nem csupán összetett térbeli szerkezete miatt, de az esztétikai egységekben való gondolkodás szükségessége miatt is, amely nélkül a külalak és funkcionalitás együttese maradéktalanul nem valósítható meg. Az előbbiek eléréséhez elengedhetetlen továbbá az orr minden szövetrétegének megfelelő pótlása is (3).

Betegeinknél az orrüreg belső bélésének kialakításához a defektus környéki, dominálóan a nasolabialis területről vett ajtószárny bőrlebenyeket alkalmaztunk. Módszerünket megfelelőnek találtuk az orrlégzési funkció biztosítására is, mivel az orrüregbe fordított bőr jól pótolja a nyálkahártyát, és kivédi a pörkösödést. A lebenyek kellő vérellátása ugyanakkor lehetőséget biztosít a porcos támasztó struktúrák azonnali pótlására is. Az orr külső bőr borítását minden esetben homloklebennyel végeztük (I. táblázat).

\section{KÖVETKEZTETÉSEK}

Ismertetett eseteink tapasztalata alapján az ajtószárny lebenyek alkalmasak lehetnek olyan speciális helyzetekben is a szövethiányok biztonságos pótlására, nagy mútéti megterhelés nélkül, amikor a környezet egy része heges, sugárkárosodott vagy az anatómiai viszonyok miatt korlátozottak a szövetvételi lehetőségek. A közleményünkben bemutatott speciális beteganyag szerencsére nem nagy számban fordul elő; sugárkezelt betegeken a szórás a nemzetközi irodalom alapján is meglehetősen nagy (2-66\%). Olyan mútéttechnikai eljárások kedvező tapasztalatát szeretnénk ismertetni, amelyek szerepe az anatómiai és élettani funkció helyreállítását szolgálják fej-nyaki tumorok radikális eltávolítása után visszamaradt, illetve szövődményként kialakult defektusok pótlására. A módszerek további előnye, hogy relatíve kis mútéti megterhelést jelentenek a betegeknek, és hogy a lebenyek a befogadó hely környezetéből könnyen nyerhetőek, bár a túldozírozott, sugárkezelt bőrterület bizonyos esetekben jelentős kockázatot jelenthet. Utóbbi esetekben legtöbbször történt már más típusú lebenyekkel (myocutan) defektuspótlás, azonban ezen lebenyek rutinszerű alkalmazása és a nagy sebészi gyakorlat ellenére sem tudtunk tartós eredményt elérni. Ilyenkor viszont a korábbi plasztikai lebenyünket - amit a sugárkezelt nyaktól távoli helyről vittünk a defektusba - jól fel tudtuk használni az ajtószárny lebeny képzéséhez. 


\section{IRODALOM}

1. Caronia F. P., Fiorelli A., Santini M., Castorina S.: A persistent tracheocutaneous fistula closed with two hinged skin flaps and rib cartilage interpositional grafting. Gen. Thorac. Cardiovasc. Surg. 2015. 10. [Epub ahead of print].

2. Godoy-Gijón E., Palacio-Aller L., González-Sabin M.: Reconstruction of the ala nasi using a malar turnover island pedicle flap. Actas Dermosifiliogr. 2015. 106. (3): 233-255.

3. Jellinek N. J., Nguyen T. H., Albertini J. G.: Paramedian forehead flap: advances, procedural nuances, and variations in technique. Dermatol. Surg. 2014. 40. Suppl. 9: S30-42.

4. Liang W., Zhou Z., Zhao Z.: Application of split gluteus maximus muscle - adipofascial turnover flap and subcutaneous tension-reducing suture technique in repair of decubitus ulcers. Int. Surg. 2014. 99. (4): 447-451.

5. Neubauer P., Cañadas K., Sasaki C. T.: Delayed platysma myocutaneous turnover flap for repair of pharyngocutaneous fistula. Am. J. Otolaryngol. 2015. 36. (1): 93-96.

6. Patel K. B., Taghinia A. H., Proctor M. R., Warf B. C., Greene A. K.: Extradural myelomeningocele reconstruction using local turnover fascial flaps and midline linear skin closure. J. Plast. Reconstr. Aesthet. Surg. 2012. 65. (11): 1569-1572.

7. Sadigh P. L., Wu C. J., Feng W. J., Hsieh C. H., Jeng S. F.: New double-layer design for 1-stage repair of orocutaneous and pharyngocutaneous fistulae in patients with postoperative irradiated head and neck cancer. Head Neck. 2015. [Epub ahead of print].

8. Shim H. C., Kim G., Choi J. H., Kim J. H., Kim E. J., Park H. J., Joh O. J., Son S. J.: The reverse nasolabial flap with a cartilage graft for the repair of a full-thickness alar defect: a single-stage procedure. Ann. Dermatol. 2014. 26. (3): 377-380.

9. Sierakowski A., Niranjan N.: Sternomastoid fascial turnover flap for Frey syndrome: An unusual case. J. Plast. Reconstr. Aesthet. Surg. 2011. 64. (2): 53-54.

10. Silva J. B., Faloppa F., Albertoni W., Gazzalle A., Cunha G. L.: Adipofascial turnover flap for the coverage of the dorsum of the thumb: an anatomic study and clinical application. J. Hand Surg. Eur. Vol. 2013. 38. (4): 371-377.

11. Tatekawa Y., Yamanaka H., Hasegawa T.: Closure of a tracheocutaneous fistula by two hinged turnover skin flaps and a muscle flap: A case report. Int. J. Surg. Case Rep. 2013. 4. (2): 170-174.

12. Zahiri H. R., Lumpkins K., Kelishadi S., Stromberg J. A., Silverman R. P., Slezak S., Goldberg N. H., Holton L., Singh D. P.: Pectoralis major turnover versus advancement technique for sternal wound reconstruction. Ann. Plast. Surg. 2013.70. (2): 211-215.

\section{Dr. Vass Gábor}

\section{SZTE ÁOK Fül-Orr-Gégészeti és Fej-Nyaksebészeti Klinika}

6725 Szeged, Tisza L. krt. 111.

vassgabor@hotmail.com 